Kostiukevych, R., Melnyk, L., Krulický, T., Kostiukevych, A., \& Melnyk, L.

(2020). A value-oriented approach to portfolio management of regional

development projects and their financial support. Journal of International Studies,

13(4), 155-170. doi:10.14254/2071-8330.2020/13-4/11

Journal

of International

Studies

\title{
A value-oriented approach to assessing regional economic development projects
}

(C) Foundation

of International

Studies, 2020

(c) $\mathrm{CSR}, 2020$

\author{
Ruslan Kostiukevych \\ Department of Management, \\ National University of $W$ ater and Environmental Engineering, \\ Ukraine \\ r.m.kostinkevich@,numm.edu.ua \\ ORCID 0000-0002-6691-2905

\section{Leonid Melnyk} \\ Finance and Environmental Economics Department, \\ National University of $W$ ater and Environmental Engineering, \\ Ukraine \\ l.v.melnyk@numm.edu.ua \\ ORCID 0000-0003-3628-9160
}

\section{Tomáš Krulický}

Institute of Technology and Business in Ceske Budejovice,

School of Expertness and Valuation,

Ceske Budejovice, Crech Republic

krulicky@mail.vstecb.c\%

ORCID 0000-0002-0378-2699

\author{
Alina Kostiukevych \\ Department of Labour and Entrepreneurship, \\ National University of $W$ ater and Environmental Engineering, \\ Ukraine \\ a.m.kostiukevich@,numm.edu.ua \\ ORCID 0000-0002-9930-9731

\section{Larysa Melnyk} \\ Finance and Environmental Economics Department, National \\ University of Water and Environmental Engineering, \\ Ukraine \\ l.m.melnyk@nuwm.edu.ua \\ ORCID 0000-0003-1731-1860
}

Abstract. Research is aimed at the improvement of methods and tools to assess the portfolio of regional economic development projects basing on the application of the system theory, algorithmic modelling, methods of expert evaluation, decomposition and synthesis. A methodical approach is proposed to establish the cause-and-effect relationships between strategic and operational goals, their

Received: October, 2019 1st Revision: October, 2020 Accepted: December, 2020 
results and indicators, underlying the determination of the value of regional economic development projects. The authors' approach allows to identify shortcomings in the structure of regional economic development projects in order to develop the regional policy. Besides, it made it possible to identify indicators, achievement of which would create the greatest value for achieving the strategy goals - those with higher strategic importance, assessed by integral indicator developed by the authors. This approach can be further used to evaluate regional economic development strategies at the levels of the united territorial communities, cities and regions. The results of assessing the strategic importance of the components of regional (local) economic development strategies should be used by policy makers as methodological approach to improve the economic project portfolio basing on value models of project management.

Keywords: project management, regional economic development, strategy, valueoriented approach.

JEL Classification: O22, R58.

\section{INTRODUCTION}

Any region or a territorial community is a complex socioeconomic system, the development of which occurs under the influence of a certain set of endogenous and exogenous factors. The strategic planning and management process consists in developing and adopting strategic decisions based on the use of positive and at the same time limitation of negative impacts of these factors. In today's strategic management theory and practice within complex socioeconomic systems, there is a widespread approach based on the definition of mission, vision, strategic and operational goals of the territory development, being implemented through the application of the program management mechanism.

Despite the relative simplicity of the conceptual strategic management model, its construction and implementation in a particular region or a community is facing a number of obstacles that can be grouped into the following blocks:

1) complexity of the mechanisms for identifying and supporting the strategic priorities of the region (community) development and their interrelation with the operational objectives of the respective strategies;

2) difficulty of establishing effective relationships between the subsystems of strategic planning and program management.

This leads to the fact that regional (local) development strategies are rarely carried out, while implemented program and projects often do not directly influence the achievement of strategic or operational objectives of the strategies. As a result, the efficiency of the financial resources use directed at development projects is low.

It is not surprising that many programs of regional economic development are not implemented in the initial form and authorities have no any responsibility for the results of their implementation. At least, it is well-known practise in countries with immature institutional environment of regional strategic planning of the economy (Kostiukevych et al., 2020). However, if the program objectives were not achieved, it confirms the hypothesis that in the program management practice little attention was paid to determining the causal relationships between the project goals and results as well as the expected results of the programs within which these projects are implemented. The same problems exist at the level of interconnection between programs and regional (local) development strategies goals these programs are directed at. 
Considering this fact, the aim of our research is to apply a value-oriented approach to assessing portfolios of regional economic development projects in combination with strategic mechanisms based on in-depth diagnosis of cause-effect relationships of the relevant strategies components.

\section{LITERATURE REVIEW}

There are a lot of scientific papers and practical manuals about methods of strategic development. International organizations fund programs aimed at broad engagement of community in the development of strategies. Significant scientific studies in the area of program management approach at the local level constitute an integral part of strategic management system in local self-government bodies (LMS).

The basis of strategic management in the community is to ensure sustainable development within a higher-level system. Emergency issues of the goals of regions development with the objectives of higherlevel systems are in detail investigated by Kh. Gizatullin, F. Garipov and Z. Garipova (2018). The application of the project approach to spatial development of the territories is substantiated by Kurushina and Petrov (2018). In particular, the authors propose to take into account the synergistic effects of interregional interaction in the process of project evaluation.

Noteworthy are the proposals of Kuklin and Korobkov (2018), Asatiani and Verulava (2017) and Bilan et al. (2020a) concerning the application of the index of well-being of the person and the territory of residence as a criterion for the socio-economic development of the region. Kislitsyna, V. Cheglakova, L. Karaulov V. and Chikisheva A. (2017) recommend using the system of target indicators from the standpoint of the integrated approach to the assessment of socio-economic development of the regions.

The result of the strategic process is the creation of the portfolio of projects, the implementation of which will ensure the achievement of strategic goals. The question of the relationship between projects and the institutional environment in which they are implemented is the subject of research carried out by a number of scholars. In this context, one should pay attention to the research of Söderlund \& Sydow (2019), Kopmann et al. (2017), Young et al. (2012).

Over the past years, researchers and practitioners have been studying the issues of achieving highperformance project portfolios and their focus on achieving strategy goals. This led to the emergence of a number of scientific studies on the use of value-oriented methods in the management of portfolios, programs and projects. These questions are substantiated in scientific works of Miia Martinsuo, Hans Georg Gemünden and Martina Huemann (2012), Nazirah Zainul Abidin and Christine L.Pasquire (2007).

Ukrainian Cities Association within the USAID "DIALOGUE" project framework conducts a sufficiently systematic work on the issues of strategic planning and project management methodology. With the USAID support in 2015, there was published a series of methodological and practical guidelines covering issues of strategic planning, financial management, methods of community engagement, fundraising, algorithms create integrated communities and their regulation (Vasylchenko et al., 2015). Some aspects of strategic development planning of the united communities are investigated in the studies (Ahmed et al., 2018; Gavatiuk et al., 2020; Milovic et al., 2020; Krayneva et al., 2017; Pavel et al., 2018). In this regard authors' recommendations are developed within the framework of prosperity and overall socioeconomic development (Bilan et al., 2020b; Ginevičius et al., 2018; Meyer \& Meyer, 2019; Mishchuk et al., 2020), sustainable development goals achievement (Krzymowski, 2020), improvement of infrastructure for regional development (Nugraha et al., 2020; Poór et al., 2018), particularly considering the problems of regional development in countries with immature economy (Kozlovskyi et al., 2019; Korbutiak et al., 2019).

Nevertheless, the issues of project and program portfolios formation taking into account their contribution to the achievement of the strategic goals are not thoroughly investigated. In particular, there are no methods and tools for developing and managing programs and projects in view of their value 
(importance, contribution) in achieving strategic goals of the appropriate level.

Problems of program management application in Ukraine at a national and regional level. In the modern system of public administration in the developed countries, program management is an effective and basic tool for solving complex problems at a global, national, regional and local level. Particularly relevant is the application of program management principles and mechanisms to address the transformation problems of organizational and economic systems, which creates conditions for quick and effective reforms. Because of implementation processes of the "Association Agreement between Ukraine, on the one hand, and the European Union, the European Atomic Energy Community and their Member States, on the other hand", which consist in a profound transformation of economic mechanisms in various fields, the importance of program management mechanisms is difficult to overestimate.

In Ukraine, however, this tool has not demonstrated efficiency either at a national, regional or local level. Analyzing the strategies and programs adopted during the years of independence, it is difficult to find one that could be achieved in time and in full. The adoption of the Law of Ukraine "On National Target Programs" in 2004 (VRU, 2004) did not solve the problem fundamentally. Attempts with hundreds of programs to resolve the situation at least somehow (many of which had not received proper funding or had not even started) through closing or freezing them did not solve the situation as well. After all, a number of strategies and programs as well as the pace of their implementation still do not correspond to the planned ones, and the goals are unattainable from the very beginning.

The vivid examples of the ineffectiveness of program management in Ukraine are the implementation processes of the Ukraine-2020 sustainable development strategy and the implementation of the plan for the association agreement between Ukraine and the European Union. For example, the dynamics of the overwhelming majority of the $25 \mathrm{key}$ indicators assessing the implementation of reforms and programs being a part of the Ukraine 2020 strategy is inadequate, and some of them are inaccessible (such as a gross domestic product of $\$ 16,000$; Ukraine will enter the 50 best countries in the world, the inflow of foreign direct investment - USD 40 billion, etc., on the perception of corruption index that Transparency International expects. Such results are mainly due to the fact that the strategy does not contain effective mechanisms for monitoring and evaluating its implementation. Experts from the Ukrainian Evaluation Association "Strengthening Decentralization in Ukraine" state that the indicators for implementing the strategy do not fully reflect the degree of problem solving. That is, when the target values of the indicators are reached, the problem will not be solved. In addition, the Government Action Plan (CMU, 2015) has no relationship with strategy indicators, and therefore its implementation cannot serve as a reliable basis for quality monitoring and evaluation. According to experts, "monitoring and evaluation systems used by Ukrainian authorities are not able to assess the implementation of the Ukraine-2020 Sustainable Development Strategy. The authorities of Ukraine practically did not carry out monitoring and evaluation of the Ukraine-2020 Sustainable Development Strategy in 2015 - 2016 and still do not carry it out".

Mechanisms of program management in Ukraine contain a number of systematic problems (MEDTU, 2016), which are inherent at a regional and local level and which we also agree on:

- state target programs have not become effective and efficient tool for solving the most important problems of development of the nation, separate branches of economy or administratively territorial units; they act as a "formal document with a declaration of intention to do something";

- within the framework of planning and use of the national budget funds, the principles of priority of the problem are not fully respected; financial resources are diverted;

- the projected amounts of financial resources of the program, incl. those of the national budget, are not consistent with the real possibilities of their financing;

- contrary to the requirements of paragraph 29 of the Program Procedure, they do not include methods for assessing the effectiveness of their implementation, which should be developed by the government 
customer, taking into account the specificity of the program and the final results;

- on the part of national customers there is a formal approach to meeting the requirements of the current legislation in the field of development and implementation of state target programs;

- no opportunity to exercise control by the public (paragraph 50 of the Procedure);

- unsatisfactory reporting by government customers: non-compliance with the deadlines for submission, information is not provided in full and not about all executives;

- lack of a transparent representation in the national budget of expenditures for national target programs financing.

As a result of reports analysis on the national target programs implementation (RRC, 2016), we found out that a number of programs do not contain clear indicators that could be used to assess the effectiveness of their implementation. Another problem is that the available indicators often do not characterize the degree of achievement, but the quality of the program management process, which leads to the situation when the program measures are implemented, the funding has been spent, and the goals have not been achieved. Under the indicator, we understand a quantitative or qualitative factor (variable) that provides a simple and reliable way to measure the achievements of the project and / or the program, reflects the changes associated with the project and / or program, or helps to assess the activities of the project implementer and / or program.

We consider it expedient to allocate resulting indicators in the programs that characterize the problem solution degree (indicators of the availability and quality of program products such as GDP per capita, unemployment rate, percentage of waste disposal, etc.) and indicators of the quality of the program implementation process (e.g. number of normative acts, methods, hearings, etc.).

To exemplify this, let's take a "Report on tasks implementation in 2017 of the National Strategy for Regional Development of Ukraine for the period until 2020" by the Ministry of Ecology and Natural Resources of Ukraine. Of the 15 indicators, only 3 characterize the state of the problem solving:

- share of the utilized waste (to the total amount of generated waste) (forecasted - 43.3\%, 2016 factually - 28.6\%, 2015 factually - 29.6\%);

- area of the natural reserve fund (forecasted - 9.09 million ha., 2017 factually- 3.98 million ha.);

- specific gravity of the nature reserve fund area to the area of the administratively territorial unit (forecasted -15\%, 2017 factually - 6,6\%).

Instead, indicators characterizing the process (such as the existence of coordination councils, guidelines, web pages, national plans, inventories, etc.) do not directly characterize the extent to which the problem is solved, but form its only prerequisites. Therefore, such indicators should serve as a tool for monitoring program implementation processes, which should be reflected in annual performance reports. While the indicators of problem solving degree form the basis for assessing the effectiveness of the program as a whole, it is advisable to make such an assessment not only after the program is completed, but also periodically (e.g. annually, when higher frequency is not set by the normative acts of the authorities that are the customers of the relevant programs).

The differentiation in the reporting of indicators of monitoring and assessment of the target programs implementation will enable on-time necessary management decisions to make changes to programs and implementation plans, and also to approach the processes of evaluating the programs effectiveness and using resources for their implementation in a more objective way. 


\section{METHODOLOGY}

The modern theory and practice of project management has at its disposal tools for these problems solving. One of these is the methodology of a value-based approach implemented in the Japanese Standard for the management of innovation projects (P2M, Program Management for Enterprise Innovation) (PMA, 2001), which can be adapted to the tasks of program management in the system of local government of the united territorial communities. The principles of and approaches to develop the project, program and portfolio management are advanced and supported by the Project Management Institute with its set of standards: The Standard for Program Management (PMI, 2017a), The Standard for Portfolio Management (PMI, 2017b), The Standard for Organizational Project Management (PMI, 2018). So, in our research we use the terminology of these PMI standards.

The essence of the methodology is that the key criteria for project success are not so much the receipt of the project product, but the assessment of its contribution to the implementation of the strategy (created value), within which this project was implemented. Ukrainian scholars S. Buschuev and F. Yaroshenko (2012) define the project value by its revenues, which ensure the product in fulfilling the requirements contained in the project mission. There are two essential conditions that guarantee the creation of the project value. The first one is the practical ability of the project manager to execute the project in accordance with the plan; the second is to find a way to harmonize the value of the project to all stakeholders through the properties of the project product. The first condition is obligatory, while the second one is a sufficient condition for project value creation.

P2M value is considered in a narrow (directly related to the project) and broad sense (the value of using the proposed approaches to project and program management for the organization). The first aspect suggests that the purpose of the project is to create a value that is defined as the characteristics of the project product, which meets the requirements of all stakeholders, and the provision of project parameters (in the first place, time and budget) to the established plans. The value of the project is intended for its stakeholders, i.e. to meet the demand of its participants. The overall satisfaction of the participants is based on the process of achieving the resulting value generated by the project.

To assess the strategic importance of operational objectives, the expert judgment method was used. The experts were the authors of this study, who were the members of the working group on the development of the Regional Development Strategy of Rivne region for the period until 2020, and therefore have appropriate expertise competences. With the help of structural and logical analysis, the relationship between the strategic importance of the operational objectives and the amount of funding was established. Value-oriented portfolio management model of regional development projects is constructed using algorithmic modelling methods.

\section{EMPIRICAL RESULTS AND DISCUSSION}

A hierarchical model for evaluating the project value in a regional development project portfolio. It is possible to ensure the high efficiency of project management as a key to the success of regional (local) sustainable development strategies, that can only be done by laying down the following principles:

- competence and motivation of project management;

- availability of methodologies adapted to the processes;

- systematic management processes and their improvement.

The strategies of strategic integration in the united territorial communities proposed in the study (Kostiukevych et al., 2020) form the basis for the development of regional development strategies, taking into account the above-mentioned principles.

In order to assess the project value in the context of the regional strategy objectives implementation, 
it is necessary to identify the causal links between the project results (Critical Success Factors, CSFs) and the indicators for achieving the results of the operational objectives of the strategy and determine their impact on the achievement of strategic objectives of the strategy.

It is only possible to qualitatively apply the proposed methodological approach when the strategy of regional development is sufficiently structured and contains well-defined strategic and operational goals, results and indicators. Otherwise, the prioritization of projects and programs should be preceded by an expert assessment of strategic and operational objectives in order to identify and quantify the results and indicators. Experts' estimates should be based on objective indicators whose predictive values should be accompanied by the description of the assumptions of the experts in combination with the methods of qualitative evaluation.

The strategic priority of the project can be determined by the indicator of the created value to achieve the objectives of the strategy, which can be measured by the impact of the project on the change in the indicators for achieving operational results, in particular:

$$
P_{i}=\sum_{j=1}^{m} I_{C S F(i j)},
$$

where $I_{C S F(j)}$ is the impact of the (i) project on the value of the (j) operational result indicator of the strategy; $\mathrm{m}$ is the number of indicators that the project affects.

$$
I_{C F S(i j)}=\sum_{k=1}^{n} \lambda_{\left(I_{o}\right)} * \frac{C S F_{(i k)}}{I_{(o)}},
$$

where $\lambda_{\left(I_{o}\right)}$ is the importance of the indicator of the target result achieving $\left(I_{(o)}\right) ; C S F_{(i k)}$ is a critical success factor of the (i) project; $(n)$ is the number of critical success factors of the $(i)$ project; $I_{(o)}$ is the indicator of result achieving of the strategy operational aim.

$$
\lambda_{\left(I_{o}\right)}=\lambda_{\left(R_{o}\right)} * X_{\left(I_{o}\right)}
$$

where $\lambda_{\left(R_{o}\right)}$ is the strategic importance of the operational purpose result $\left(R_{o}\right)$, to which the corresponding indicator belongs; $X_{\left(I_{O}\right)}$ is an expert assessment of the conformity of the indicator of the operational purpose result $\left(R_{o}\right)$. Such an assessment can be done on a discrete scale, where «1» corresponds; «0,5» partially corresponds; «0» does not correspond.

The strategic importance of the operational goal result $\left(R_{o}\right)$ can be determined by the following relationship:

$$
\lambda_{\left(R_{o}\right)}=\lambda_{\left(G_{o}\right)} * X_{\left(R_{o}\right)}
$$

here $\lambda_{\left(G_{o}\right)}$ is the strategic importance of the operating target $\left(G_{o}\right) ; X_{\left(R_{o}\right)}$ is an expert assessment of the correspondence of the result $\left(R_{o}\right)$ to the operational goal $\left(G_{o}\right)$. Such an assessment can be done on a discrete scale, where «1» corresponds; «0,5» partially corresponds; «0» does not correspond.

$$
\lambda_{\left(G_{o}\right)}=\frac{\sum_{j=1}^{m} X_{R s(j)}}{m},
$$

where $X_{R s(j)}$ is an impact of the operational goal result $\left(R_{o}\right)$ on the achievement of the corresponding strategic goal $\left(G_{S}\right) ;(m)$ is the number of results of strategic goals achievement. The estimation of the influence should be expertly carried out on a discrete scale, where «1» is an immediate positive effect, «0,5» - mediated negative influence, «0» - no connection, «- $0,5 »-$ mediated negative influence, «-1» - direct negative influence; $(v)$ is the number of strategic outcomes belonging to the strategic goal $\left(G_{s}\right)$.

The local strategic importance of the operating objective $\left(G_{o}\right)$ for a specific strategic goal $\left(G_{s}\right)$ can be determined by the formula: 


$$
X_{G s(j)}=\frac{\sum_{k=1}^{v} X_{R s(j k)}}{v},
$$

where $X_{R s(j k)}$ is the effect of the operating target $\left(G_{o}\right)$ on the achievement of $(k)$ result of $(j)$ strategic goal $\left(G_{S}\right) ;(v)$ is the number of results belonging to the $(j)$ strategic goal $\left(G_{S}\right)$. This indicator is not used in further calculations, but it is important to establish causal relationships between strategic and operational goals.

The application of the method in the early stages of the strategy (program) development makes it possible to avoid the scattering of resources and increase the level of emergency of the strategic, operational objectives of the strategy (program) with the objectives of the project portfolio. The effectiveness of the method at later stages of strategy (program) implementing is reduced as the evaluation results can be applied only to make adjustments to the relevant strategies or as a part of the knowledge management system (to take into account the experience gained in developing new strategies and programs).

In the evaluation system it is advisable to define the importance of the strategic goals of the development strategy. However, it should be noted that such evaluation should be conducted by key stakeholders, not by experts. Since the prioritization of goals reflects the strategic vision of community development as key stakeholders and is the result of a political dialogue, they should be the subjects of establishing such priority. However strategic goals of development strategies are not often prioritized. In such cases, they can be considered equal.

We will demonstrate the use of the proposed model on the example of the "Regional Development Strategy of Rivne Region for the period until 2020" (RRC, 2014). The strategy consists of:

1) strategic goal $\left(G_{S(1)}\right)$ - "Economic Potential Development" consists of four operational goals $\left(G_{o(1.1)} \ldots G_{o(1.4)}\right)$ and is described by nine results $\left(R_{S(1.1)} \ldots R_{S(1.9)}\right)$;

2) strategic goal $\left(G_{S(2)}\right)$ - "Rural development" consists of three operational goals $\left(G_{o(2.1)} \ldots G_{o(2.3)}\right)$ and is described by seven results $\left(R_{S(2.1)} \ldots R_{S(2.7)}\right)$;

3) strategic goal $\left(G_{S(3)}\right)$ - "Human Resource Development" consists of three operational goals $\left(G_{o(3.1)} \ldots G_{o(3.3)}\right)$ and is described by five results $\left(R_{S(3.1)} \ldots R_{S(3.5)}\right)$.

The achievement of each operating goal $\left(G_{o(i j)}\right)$ requires the receipt of a certain set of operating results:

$$
G_{o}=\left[\begin{array}{ccc}
\mathrm{R}_{\mathrm{o}(1.1)} & \ldots & \mathrm{R}_{\mathrm{o}(1 . \mathrm{n})} \\
\ldots & \ldots & \ldots \\
\mathrm{R}_{\mathrm{o}(\mathrm{m} .1)} & \ldots & \mathrm{R}_{\mathrm{o}(\mathrm{m} \cdot \mathrm{n})}
\end{array}\right] .
$$

Thus, the research strategy contains 62 operational results with 51 indicators $\left(I_{o}\right)$. Without analyzing the content of the indicators, even a quick survey shows deficiencies in their definition. In particular, we believe that the inequality has to continue while developing the strategy

$$
\sum N_{R_{o}} \leq \sum N_{I_{o}}
$$

where $N_{R_{o}}$ is the number of operational results; $N_{I_{o}}$ is the number of indicators for achieving operational results. If inequality (8) is not performed, it means then that at least one indicator is used to measure several operational results. Consequently, it is impossible to establish cause-and-effect relationships regarding which indicator characterizes the receipt of a particular result. Conversely, it is quite logical to have several indicators used to describe a single result.

A qualitative analysis of cause-effect relationships of type $\left(R_{o(i j)} \rightarrow I_{o(i j)}\right)$ shows that no indicators are set at all for up to 22 operating results that make up $35.5 \%$ of the total number of the results. Instead, 12 in 51 indicators do not relate to any of the operational results.

A striking example form the results of the operational objective "4.1. Economic development of the northern part of Rivne region (equalization of territorial disparities)", for three of which no indicators are set at all, and two indicators do not reflect any of the following operational results. 
Correspondence of indicators to the operating objective results "4.1. Economic development of the northern part of Rivne region (equalization of territorial disparities)"

\begin{tabular}{|c|c|c|}
\hline ID & Operating results $\left(R_{o}\right)$ & Indicators $\left(I_{o}\right)$ \\
\hline 1.4.1. & $\begin{array}{l}\text { setting up new enterprises in the northern part of } \\
\text { Rivne region }\end{array}$ & $\begin{array}{l}\text { attracted investments volumes in the northern } \\
\text { parts of Rivne regions }\end{array}$ \\
\hline 1.4.2. & $\begin{array}{l}\text { expansion of production capacities of granite } \\
\text { factories and peat production enterprises of the } \\
\text { district }\end{array}$ & - \\
\hline 1.4.3. & $\begin{array}{l}\text { in-depth timber processing and export potential } \\
\text { growth of woodworking enterprises }\end{array}$ & - \\
\hline 1.4 .4 & $\begin{array}{l}\text { creation of conditions for self-employment of the } \\
\text { population in the northern parts of the region }\end{array}$ & $\begin{array}{l}\text { household income in the northern parts of the } \\
\text { region }\end{array}$ \\
\hline 1.4 .5 & $\begin{array}{l}\text { fertility restoration and reduction of land pollution } \\
\text { in the Polissya zone }\end{array}$ & - \\
\hline \multirow[t]{3}{*}{ 1.4.6. } & $\begin{array}{l}\text { improvement of the infrastructure of the northern } \\
\text { parts of the region }\end{array}$ & number of improved social infrastructure objects \\
\hline & ? & $\begin{array}{l}\text { dynamics of the population number in the } \\
\text { northern parts of the region }\end{array}$ \\
\hline & $?$ & number of jobs in the northern parts of the region \\
\hline
\end{tabular}

Applying the formula (6), the strategic priority of the operational objectives of the "Regional Development Strategy of Rivne Region for the period until 2020" is calculated.

Table 2

Strategic Priority of Operational Objectives

"Regional Development Strategy of Rivne Region for the period until 2020"

\begin{tabular}{|l|c|c|c|c|}
\hline \multicolumn{1}{|c|}{ Operational Purpose } & \multicolumn{2}{|c|}{ Local Indicators } & \multicolumn{2}{c|}{$\begin{array}{c}\text { Integral } \\
\text { Indicator }\end{array}$} \\
\cline { 2 - 5 } & $X_{G s(1)}$ & $X_{G s(2)}$ & $X_{G S(3)}$ & $X_{G S}$ \\
\hline 1.1. Setting up new high-tech industries and innovative enterprises & 0,611 & 0,357 & 0,300 & 0,452 \\
\hline 1.2. Stimulating small and medium businesses development & 0,778 & 0,571 & 0,650 & 0,679 \\
\hline 1.3. In-land tourism development & 0,556 & 0,643 & 0,550 & 0,583 \\
\hline $\begin{array}{l}\text { 1.4. Economic development of the northern parts of Rivne region } \\
\text { (equalization of territorial disproportions) }\end{array}$ & 0,611 & 1,000 & 0,600 & 0,738 \\
\hline 2.1. Increase in the value added of agricultural products & 0,611 & 0,571 & 0,200 & 0,500 \\
\hline $\begin{array}{l}\text { 2.2. Development of rural territories and infrastructure around small } \\
\text { towns and villages }\end{array}$ & 0,222 & 0,357 & 0,100 & 0,238 \\
\hline 2.3. Support on employment for rural population & 0,333 & 0,429 & 0,700 & 0,452 \\
\hline 3.1. Population adaptability increase to the labor market needs & 0,222 & 0,286 & 0,700 & 0,357 \\
\hline 3.2. Awareness and social activity increasing of the residents & 0,000 & 0,143 & 0,300 & 0,119 \\
\hline 3.3. Improvement of regional development management & 0,778 & 0,714 & 0,700 & 0,738 \\
\hline
\end{tabular}

Developed by the authors on the basis of the "Regional Development Strategy of Rivne region for the period until 2020"

Applying the dependencies (3) and (4) for the regional strategy under study, the strategic importance of the described operational results and indicators (see Figure 1) is determined.

The strategic importance analysis of the components of "Regional Development Strategy of Rivne region for the period until 2020" made it possible to identify 7 indicators, achievement of which would create the greatest value for achieving the strategy goals (strategic importance of 0.738 and 0.679 ). These indicators describe the achievement results of the operational objectives " 1.2 - Stimulating of small and medium businesses development "and "3.3 - Improvement of regional development management". 
Projects resulting in these operational objectives should have a high priority in the project portfolio for strategy implementation plan. On the other hand, projects the results of which will be related to indicators of low strategic value or will not affect the realization of the strategy goals at all (e.g. indicators located at the bottom of Figure 1b) should be classified as a low priority project group or rejected at all.

The economic consequences of the proposed approach underlie the fact that in the context of limited financial resources, those projects will be prioritized that will ensure the achievement of the most significant operational and, consequently, strategic outcomes. The analysis of the expected funding amount for the implementation plans of the Regional Development Strategy of Rivne region for the period until 2020 shows, for example, an imbalance in the structure of the budget.
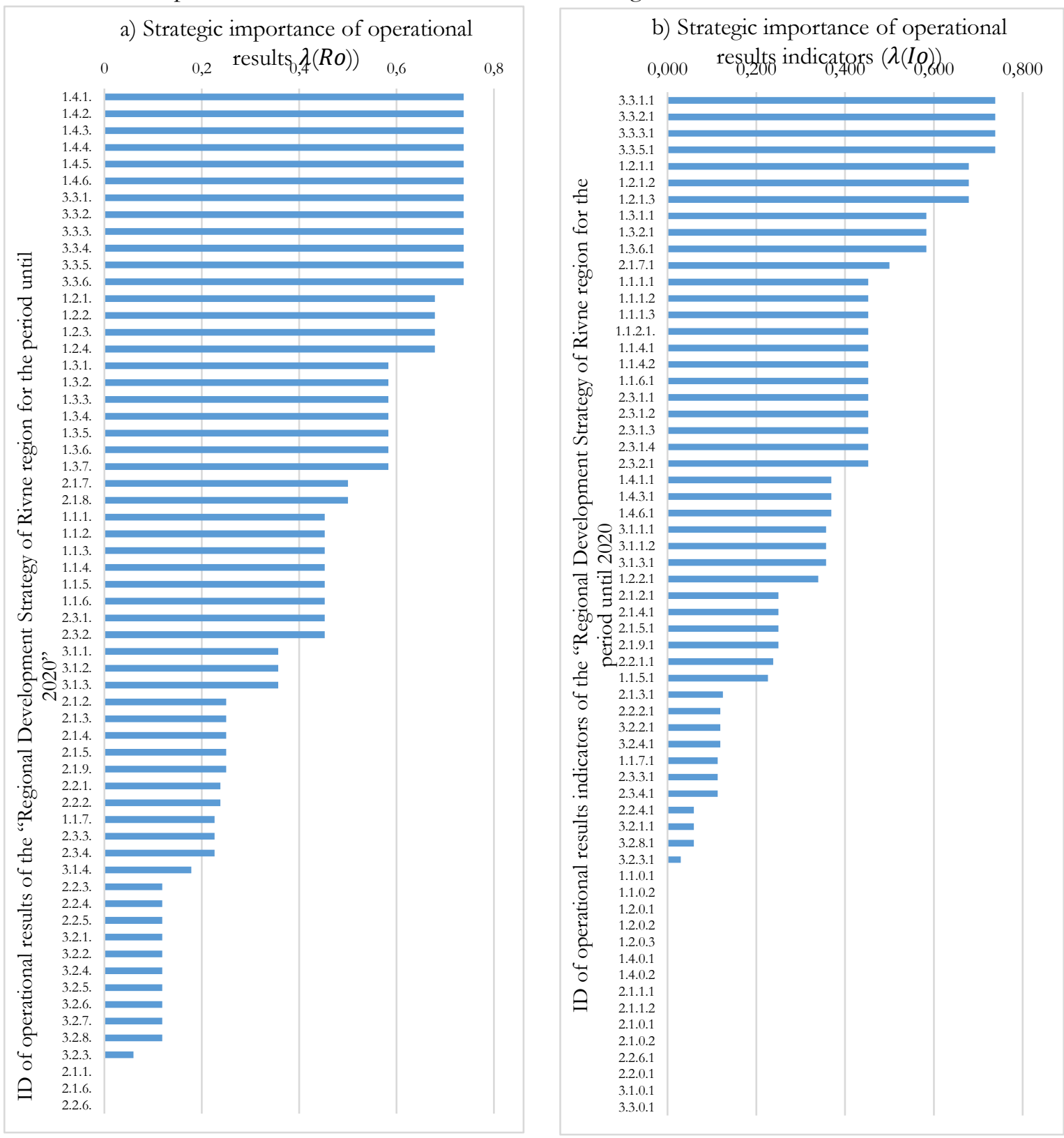

Figure 1. Strategic importance of the results $\left(\left(\lambda_{\left(R_{o}\right)}\right)\right.$ and indicators $\left(\lambda_{\left(I_{o}\right)}\right)$ of operational objectives of the "Regional Development Strategy of Rivne region for the period until 2020" Developed by the authors on the basis of the "Regional Development Strategy of Rivne region for the period until 2020" 
Comparison of the strategic priority of the "Regional Development Strategy of Rivne region for the period until 2020" operational objectives with the amount of expected funding

\begin{tabular}{|l|c|c|c|}
\hline \multicolumn{1}{|c|}{ Operational Purpose } & $\begin{array}{c}\text { Integral } \\
\text { indicator, } \\
X_{G S}\end{array}$ & $\begin{array}{c}\text { Expected } \\
\text { funding amount, } \\
\text { UAH mln. }\end{array}$ & $\begin{array}{c}\text { Share in the } \\
\text { funding } \\
\text { structure, } \%\end{array}$ \\
\hline $\begin{array}{l}\text { 1.1.Setting up new high-tech industries and innovative } \\
\text { enterprises }\end{array}$ & 0,452 & 4413,94 & 13,1 \\
\hline $\begin{array}{l}\text { 1.2. Stimulating small and medium businesses } \\
\text { development }\end{array}$ & 0,679 & 84,62 & 2,5 \\
\hline 1.3. In-land tourism development & 0,583 & 54,89 & 1,6 \\
\hline $\begin{array}{l}\text { 1.4. Economic development of the northern parts of } \\
\text { Rivne region (equalization of territorial disproportions) }\end{array}$ & 0,738 & 36,45 & 1,1 \\
\hline 2.1. Increase in the value added of agricultural products & 0,500 & 687,73 & 20,3 \\
\hline $\begin{array}{l}\text { 2.2. Development of rural territories and infrastructure } \\
\text { around small towns and villages }\end{array}$ & 0,238 & 1925,67 & 56,8 \\
\hline 2.3. Support on employment for rural population & 0,452 & 11,29 & 0,3 \\
\hline $\begin{array}{l}\text { 3.1. Population adaptability increase to the labor market } \\
\text { needs }\end{array}$ & 0,357 & 170,56 & 5,0 \\
\hline $\begin{array}{l}\text { 3.2. Awareness and social activity increasing of the } \\
\text { residents }\end{array}$ & 0,119 & 193,51 & 5,7 \\
\hline $\begin{array}{l}\text { 3.3. Improvement of regional development } \\
\text { management }\end{array}$ & 0,738 & 227,14 & 6,7 \\
\hline
\end{tabular}

As it can be seen from Table 3, to achieve operational objective 2.2, which has a low priority level (0.238), the plans for the Strategy implementation foresee more than a half of all resources (56.8\%). In this case, the indicators 2.2.0.1, 2.2.6.1 (see Figure 1) do not relate to the operating results, and the result of 2.2.6 does not affect the achievement of the operational objective at all. 2.2. Instead, one of the main priorities of the region's development is "1.2. Stimulating the development of small and medium-sized businesses" comprises only $2.5 \%$ of the total budget of the Strategy's implementation plans in the funding structure. Such an imbalance of the Strategy results in the reduction of financial resources use efficiency aimed at implementation of a projects portfolio.

To determine the projects priority of the "Plan for 2015-2017 on the implementation of the Development Strategy of Rivne region for the period until 2020" (RRC, 2015) and the "Plan for 2018 - 2020 on the implementation of the Development Strategy of Rivne region for the period until 2020" (RRSA, 2017) is impossible, since the of indicator values for the operational goals achievement have not been set. In addition, though the plan for 2015-2017 contains project descriptions with expected results indications, they are not always quantified and often lack direct relevance to the indicators of the strategy operational objectives. And the strategy implementation plan for 2018-2020 contains only project names without indicating the expected results, although funding sums are determined. Mechanism of regional development projects portfolio formation based on the application of a value-based approach. The development of the plan for strategy implementing and projects portfolio forming with the use of value-oriented management model can be carried out on the basis of the above-mentioned concept of establishing the strategic importance of indicators, results, operational and strategic objectives.

The so called $5 \mathrm{E}+2 \mathrm{~A}$ approach can be applied in this case, which consists of evaluating seven criteria of project value: efficiency (resources use efficiency); effectiveness (performance from the stakeholders' position); earned value (value added); ethics; ecology; accountability; acceptability (PMA, 2001).

However, the project value (its influence on the strategic goals implementation) is not the only criterion to be added to the project portfolio. An important factor in the formation of a portfolio structure is the level of project risk, which characterizes the probability of failure to achieve project goals due to exogenous 
or endogenous factors. The combination of the degree of value and risk will determine the class of the project in the portfolio and the corresponding mechanism of its strategic management. In practice, the use of value-oriented models of project management, the following project classification is applied according to the following features:

- high value - low risks (pearls) (such projects should receive a priority status and be included in the plan of strategy realization with the predominant financing from the regional development budget (community);

- high value - high risks (oyster) (as there is a high probability not to reach the project result, it is expedient to diversify risks through the use of the mechanisms of public-private partnership, share participation or grant financing);

- low value - low risks (bread and oil) (such projects do not give a significant impetus to the outdated development of the region (community), but they can be implemented in order to balance the riskiness of the portfolio in general; their share in the portfolio should be reduced over time);

- low value - high risks (white elephants) (such projects need to clarify the concept, content, or structure of funding before being introduced into the strategy implementation plan).

Taking this into account, the portfolio management mechanism of the region (community) is constructed (Fig. 2).

The design office, which may have a different structure depending on the availability of human resources and their competence, plays a key role in effective portfolio management mechanism formation of the regional development strategy project. The project office can function in the format of a working group composed of specialists of the executive committee of the council, deputies, representatives of local businesses and the public at approximately equal proportions. Separate tasks requiring special knowledge may be entrusted to the relevant units of the executive committee. The methodological guidance of the project office may be carried out by a professional strategic planning consultant who may be involved under contractual conditions.

The implementation of the strategy implementation plan should be monitored by a working group with a wide involvement of the public. It is expedient to empower the working group with exclusion (from the strategy implementation plan) of the projects (technical tasks) that have lost their priority (urgency) for some reason, and/or providing suggestions on the change of the regional strategy. 


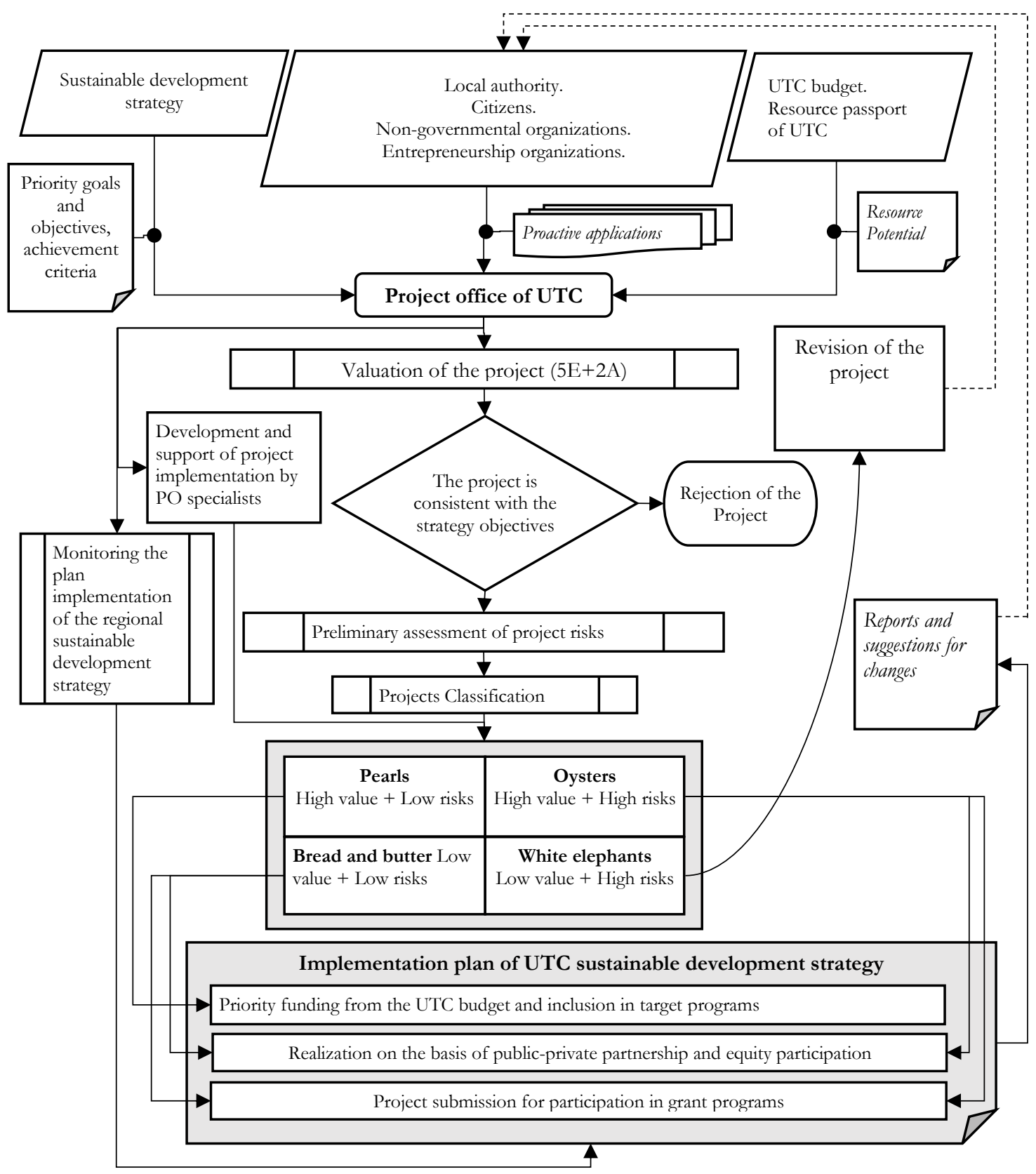

Figure 2. Value-oriented portfolio management model for regional development projects Developed by the authors

\section{CONCLUSION}

In this paper we aimed applying a value-oriented approach to managing portfolios of regional development strategy projects in combination with strategic mechanisms based on in-depth diagnosis of cause-effect relationships of the relevant strategies components can significantly improve the efficiency of financial resources use.

As a result of the methodological approach approbation in the Regional Development Strategy of Rivne region for the period until 2020, the imperfection of its structure was revealed. In particular, there is a lack of links between a part of the operational goals, their results and indicators. Such a structure caused 
a significant discrepancy in the financing of projects with strategic priorities of operational objectives. This leads to a reduction in the efficiency of financial resources use and complicates the achievement of Strategy's strategic objectives.

The developed value-oriented portfolio management model for regional development projects contains various alternative scenarios for the formation of a strategy implementation plan. Depending on the strategic priority of a particular project, it is recommended to apply the appropriate scheme for its funding. Application of modern value-oriented approaches to portfolio management processes creates the prerequisites for the organization of a sustainable strategy process, which will be highly manageable and productive.

The main result of the proposed program management model's application is that the strategic management mechanism at the regional level is aimed at ensuring a high emergency degree of the projects and programs objectives as well as operational and strategic results with the strategic objectives of the regional development strategies.

The proposed methodological approaches can be applied at different stages of the of strategy process: from the stage of setting strategic and operational goals to reporting on the results of strategies and target programs implementation. Due to the sufficient degree of the developed models structuring, they can be easily integrated into any automated decision support system.

\section{REFERENCES}

Abidin, N.Z. \& L.Pasquire C. (2007). Revolutionize value management: A mode towards sustainability. International Journal of Project Management, 25(3), 275-282.

Ahmed, R. R., Vveinhardt, J., \& Streimikiene, D. (2018). The direct and indirect impact of Pharmaceutical industry in Economic expansion and Job creation: Evidence from Bootstrapping and Normal theory methods. Amfiteatru Economic, 20(48), 454-469.

Asatiani, M., Verulava, T. (2017). Georgian Welfare State: Preliminary Study Based on Esping-Andersen’s Typology. Economics and Sociology, 10(4), 21-28. doi:10.14254/2071-789X.2017/10-4/2

Bilan, Y., Mishchuk, H., Samoliuk, N., \& Yurchyk, H. (2020a). Impact of Income Distribution on Social and Economic Well-Being of the State. Sustainability, 12(1), 429; doi:10.3390/su12010429

Bilan Y., Mishchuk, H., Roshchyk, I. \& Kmecova I. (2020b). Analysis of Intellectual Potential and its Impact on the Social and Economic Development of European Countries. Journal of Competitiveness, 1, 22-38. https://doi.org/10.7441/joc.2020.01.02

CMU (2015). Regulation No. 213-p of the Cabinet of Ministers of Ukraine "On approval of the plan of measures for the activity program implementation of the Cabinet of Ministers of Ukraine and Sustainable development strategy "Ukraine - 2020" in 2015». Retrieved March 4, 2015, from http://zakon2.rada.gov.ua/laws/show/213-2015-\%D1\%80

Gavatiuk, L., Korbutiak, A., Sokrovolska, N., Karvatskyi, M., \& Yurii, E. (2020). The system of the key indicators of formation of attractive investment climate of Ukraine and peculiarities of their management. Problems and Perspectives in Management, 18(1), 154-170.

Ginevičius, R., Gedvilaite, D., Stasiukynas, A., Čepel, M. (2018). Integrated Assessment of the Socioeconomic Systems' Development. Economics and Sociology, 11(1), 11-21. doi:10.14254/2071-789X.2018/11-1/1

Gizatullin Kh. N., Garipov, F. N., \& Garipova, Z. F. (2018). Management of the Structural Transformation of Regional Economy. Ekonomika regiona [Economy of Region], 14(1), 43-52.

Kislitsyna V. V., Cheglakova L. S., Karaulov V. M., \& Chikisheva A. N. (2017). Formation of the integrated approach to the assessment of socio-economic development of regions. Ekonomika regiona [Economy of Region], 13(2), 369380 .

Kopmann, J., Kock, A., Killen, C.P., \& Gemünden H.G. (2017). The role of project portfolio management in fostering both deliberate and emergent strategy. International Journal of Project Management, 35(4), 557-570. 
Korbutiak, A., Lysenko, Z., Sokrovolska, N., Oleksyn, A., \& Yurii, E. (2019). United territorial communities in Ukraine in the context of fiscal decentralization. Problems and Perspectives in Management, 17(2), 217-227.

Kostiukevych, R., Mishchuk, H., Zhidebekkyzy, A., Nakonieczny, J., \& Akimov, O. (2020). The impact of European integration processes on the investment potential and institutional maturity of rural communities. Economics and Sociology, 13(3), 46-63. doi:10.14254/2071-789X.2020/13-3/3

Kozlovskyi, S., Grynyuk, R., Baidala, V., Burdiak, V., \& Bakun, Y. (2019). Economic Security Management of Ukraine in Conditions of European Integration. Montenegrin Journal of Economics, 15(3), 137-153.

Krayneva, R., Bugaev, A., Zhuravleva, T., \& Vojtovič, S. (2017). Management and promotion of economic innovation potential. Journal of International Studies, 10(1), 146-158. doi:10.14254/2071-8330.2017/10-1/10

Krzymowski, A. (2020). The European Union and the United Arab Emirates as civilian and soft powers engaged in Sustainable Development Goals. Journal of International Studies, 13(3), 41-58. doi:10.14254/2071-8330.2020/13$3 / 3$

Kuklin A. A., \& Korobkov I. V. (2018). Selection of an Effective Trajectory of Regional Socio-Economic Development. Economica Regiona [Economy of Region], 14(4), 1145-1155.

Kurushina, E. V., \& Petrov, M. B. (2018). Performance Criteria of Spatial Development Projects Based on Interregional Integration. Ekonomika regiona [Economy of Region], 14(1), 176-189.

Martinsuo, M., Gemünden, H.G. \& Huemann M. (2012). Toward strategic value from projects. International Journal of Project Management, 30(6), 637-638.

MEDTU (2016). Ministry of Economic Development and Trade of Ukraine. The state of execution of state target programs in the year 2016. Retrieved from http://www.me.gov.ua/Documents/Download?id=0f2d16975c03-4c5f-be4b-939a1138cdea

Meyer, N., \& Meyer, D. F. (2019). A comparative analysis of developmental progression: The case of Poland and South Africa. Administratie si Management Public, (33), 147-164.

Milovic, N., Jocovic, M., \& Djurisic, V. (2020). The Role of Entrepreneurship in the Development of Local SelfGovernments in Montenegro. Transformations in Business \& Economics, 19(2), 159-170.

Mishchuk, H., Bilan, S., Yurchyk, H., Akimova, L., \& Navickas, M. (2020). Impact of the shadow economy on social safety: The experience of Ukraine. Economics \& Sociology, 13(2), 284-298.doi:10.14254/2071-789X.2020/13$2 / 19$

Nugraha, A. T., Prayitno, G., Situmorang, M. E., \& Nasution, A. (2020). The role of infrastructure in economic growth and income inequality in Indonesia. Economics \& Sociology, 13(1), 102-115. doi:10.14254/2071-789X.2020/13$1 / 7$

Order No. 5/2015 of the President of Ukraine "Sustainable development strategy "Ukraine - 2020". Retrieved October 12, 2020, from http://zakon2.rada.gov.ua/laws/show/5/2015.

Pavel, A., Moldovan, B., Neamtu, B. \& Hintea, C. (2018). Are Investments in Basic Infrastructure the Magic Wand to Boost the Local Economy of Rural Communities from Romania? Sustainability, 10(10), 3384.

PMA (2001). Project Management Association of Japan. The Guidebook for Project and Program Management for Enterprise Innovation (P2M).

PMI (2017a). The Standard for Program Management. Fourth Edition. URL: https://www.pmi.org/pmbok-guidestandards/foundational/program-management

PMI (2017b). Project Management Institute. The Standard for portfolio management-Fourth Edition. URL: https://www.pmi.org/pmbok-guide-standards/foundational/standard-for-portfolio-management/fourthedition

PMI (2018). The Standard for Organizational Project Management. URL: https://www.pmi.org/pmbok-guidestandards/foundational/organizational-project-management

Poór, J., Juhász, T., Machová, R., Bencsik, A. \& Bilan, S. (2018). Knowledge management in human resource management: Foreign-owned subsidiaries' practices in four CEE countries. Journal of International Studies, 11(3), 295-308. doi:10.14254/2071-8330.2018/11-3/23

RCC (2016). Small and Medium Enterprises Development Program activities in Rivne for 2016-2017. Retrieved January 14, 2016, from http://economy.rv.ua/development_programs/development_programs2/. 
RRSA (2015). Plan for 2015-2017 on the implementation of the Development Strategy of Rivne region for the period until 2020, approved by the governor of Rivne regional state administration. Retrieved May 27, 2015, from http://oblrada.rv.ua/documents/rishennya/6_sklikannya.php.

Young, R., Young, M., Jordan, E. \& O'Connor, P. (2012). Is strategy being implemented through projects? Contrary evidence from a leader in New Public Management. International Journal of Project Management, 30(8), 887-900.

RRSA (2017). Plan for 2018-2020 on the implementation of the Development Strategy of Rivne region for the period until 2020, approved by the governor of Rivne regional state administration. Retrieved December 01, 2017, from http://oblrada.rv.ua/documents/rishennya/7_sklikannya.php.

RRC (2014). Rivne regional council. Regional Development Strategy of Rivne Region for the period until 2020 , approved by the Rivne regional council decision. Retrieved December 18, 2014, from http://www.rv.gov.ua/sitenew/main/ua/catalog/item/5106.htm.

RRC (2016). Reports on implementation of programs in Rivne region. Retrieved from http://oblrada.rv.ua/documents/oblprogram/zvit.php.

Söderlund, J., \& Sydow J. (2019). Projects and institutions: towards understanding their mutual constitution and dynamics. International Journal of Project Management, 37(2), 259-268.

Vasylchenko G., Parasyuk I., \& Yeremenko N. (2015). Planning of the development of territorial communities. K.: LLC«ENTERPRISE «VNA».

VRU (2004). Law of Ukraine 1621-IV “On National Target Programs”. Retrieved March 18, 2004, from http://zakon.rada.gov.ua/laws/show/1621-15.

Yaroshenko F. A., \& Buschuev, S. D. (2012). Management of innovative projects and programs based on the knowledge system P2M. K.: "Summit-book". 